\title{
Reforming occupational pensions in Germany
}

Received: 1st August, 2000

\section{Karl Wirth*}

completed the requirements for his PhD at the University of Leipzig, in his native Germany, in late 1999. His PhD thesis, from which this article was derived, was a comparative analysis of retirement income provision in Germany, the United Kingdom and the United States. He is currently working as a consultant in the London offices of HCM International, a global HR consulting firm.

\begin{abstract}
This paper gives a brief overview of the occupational pension arrangements currently available in Germany. It focuses on the weaknesses of the current system and suggests how to improve the regulatory environment based on experience from the UK and US. The article notes that, despite the statutory restrictions, some German employers have found innovative solutions on how to provide adequate pension benefits and explores three of these model plans.
\end{abstract}

Keywords: occupational pensions; regulatory environment; funding; taxation; alternative pension benefits

\section{Introduction}

In early 2001, the German Supreme Court (Bundesverfassungsgericht) is expected to publish a ruling on the unequal tax treatment of social security pensions in the public and private sector. It is anticipated that it will impose a deadline on legislators to implement a level playing-field in terms of taxation. In addition to social security, legislators are expected to include occupational pensions in their pension reform.

However, the likely design of this reform as well as the extent to which occupational pensions will be included is unknown.

In this paper, the status quo of

*Karl Wirth

(HCM International, 7th Floor, St Vincent House, 30 Orange Street, London WC2 $\mathrm{H} 7 \mathrm{HH}$.

Tel: +44 (0)20 7747 0200; Fax: +44 (0)20 78396600 ; e-mail:

krwirth@hcmintl.com) occupational pension schemes in Germany will be introduced to give the reader an insight to the current statutory environment. This is followed by a number of reform proposals that are likely to increase participation without putting too many additional (financial) constraints on German employers. Each proposal reflects the current regulatory environment of occupational pensions in the UK and the USA.

In the absence of a proper occupational pension reform, German employers are reluctant to incur new pension promises. Instead, some companies have found innovative ways to establish alternative benefit arrangements.

\section{Status quo of German occupational pension schemes}

\section{Types of pension schemes}

The German occupational pensions law (Gesetz zur Verbesserung der betrieblichen Altersversorgung, BetrAVG) specifies that:

- the sponsor of an occupational pension scheme (OPS) must be the employer 
- any OPS must cover at least one of three relevant life event risks (ie, longevity, invalidity or death)

- benefits must be provided as a pension.

Consequently, OPSs are of the defined benefit type only. However, employers have some flexibility in funding OPSs. Pensions may be provided through internally or externally funded pension schemes. The main characteristics of available funding vehicles are discussed below.

Internally funded pension schemes Internally funded pension schemes, the so-called Direktzusagen (or direct commitments), are pension liabilities on the balance sheet of the sponsoring company. These pensions liabilities must be matched by corresponding assets creating 'book reserves'.

'Book reserves' are insured against the bankruptcy of the sponsoring company by the Pensions-Sicherungs-Verein auf Gegenseitigkeit (PSVaG), which is organised similarly to the US Pension Benefit Guarantee Corporation. The PSVaG is an important security net for members who would otherwise rank equally with other creditors.

However, Direktzusagen may have some significant disadvantages over externally funded pension schemes. As Davis ${ }^{1}$ suggests, in general internal investment opportunities do not have to meet market criteria for profitability, and sometimes firms even have difficulties in 'finding profitable internal investment opportunities' at all. Also, in declining industries, companies with Direktzusagen may have a competitive disadvantage over firms without liabilities.

\section{Externally funded pension schemes}

There are three different types of indirect commitments or externally funded pension schemes:
- Pensionskassen (pension funds)

- Direktversicherungen (direct insurance); and

- Unterstützungskassen (support funds).

Pensionskassen are legally independent mutual insurance associations

(Versicherungsverein auf Gegenseitigkeit). The sponsoring company offers eligible employees membership in their occupational pension scheme almost on an individual basis (see below) and uses the Pensionskasse as a funding vehicle. Therefore, the beneficiaries have a legal claim against the Pensionskasse instead of the sponsor. However, the sponsoring firm continues to be responsible for funding.

Direktversicherungen are life insurance contracts taken out by the employer for the benefit of the insured. In return, beneficiaries have a legal claim against the insurance company, which has issued the contract. However, legal ownership of the contract remains with the sponsor and may be used as collateral for a loan.

Pensionskassen and Direktversicherungen are subject to the extensive regulations of German insurance law. Therefore, they are also subject to supervision by the independent German insurance regulator (Bundesaufsichtsamt für das Versicherungswesen).

Unterstützungskassen do not give members a legal right to their pension benefits. However, through several court decisions in the past members of support funds have de facto been given this right. In this regard, support funds are similar to Anglo-Saxon pension trust funds.

Furthermore, support funds are hardly regulated at all. As a result, the decisionmaking process (eg, investment decisions) is dominated by the sponsoring company.

\section{Number of schemes}

There are 146 Pensionskassen (five of which are closed to active members), ${ }^{2}$ 
Table 1: Participation in OPS of German employees working in the manufacturing and trade sectors (1999)

\begin{tabular}{llll}
\hline $\begin{array}{l}\text { Companies with } \\
\ldots \text { employees }\end{array}$ & Manufacturing & $\begin{array}{l}\text { Companies with } \\
\text {... employees }\end{array}$ & Trade \\
\hline N/A & N/A & $3-5$ & $10 \%$ \\
$20-49$ & $21 \%$ & $6-9$ & $14 \%$ \\
$50-99$ & $36 \%$ & $10-19$ & $12 \%$ \\
$100-199$ & $45 \%$ & $20-49$ & $15 \%$ \\
$200-499$ & $56 \%$ & $50-199$ & $23 \%$ \\
$500-999$ & $68 \%$ & $200-500$ & $32 \%$ \\
1,000 and over & $86 \%$ & 500 and over & $55 \%$ \\
On average & $64 \%$ & On average & $28 \%$ \\
\hline
\end{tabular}

Source: ifo Institut für Wirtschaftsforschung.

$5.39 \mathrm{~m}$ Direktversicherungen and an estimated 5,000 Unterstützungskassen in Germany. The number of Direktzusagen is unknown, mainly because private companies do not have the statutory duty to publish their balance sheets.

\section{Total pension assets and liabilities}

Direktzusagen are the most common OPS type with a market share of 56.7 per cent of total pension liabilities, followed by Pensionskassen with 22.3 per cent, Direktversicherungen with 13.1 per cent and Unterstützungskassen with 7.9 per cent.

Total assets of German occupational pension schemes amount to $€ 124$.2bn or 6.5 per cent of GDP (1998). This figure, of course, excludes 'book reserves', since they are not externally funded.

\section{Participation}

As Table 1 indicates, OPSs are not particularly widespread among German employees, especially among employees of small and medium enterprises (SME). For employers with fewer than 50 employees, the participation rate is 21 per cent in the manufacturing sector and 15 per cent or below in the trade sector. On average, 28 per cent of employees in trade industry and 64 per cent in manufacturing industry are members of an OPS (1999). ${ }^{3}$
There are two main reasons for this relatively low participation rate:

- The generous replacement ratio of the social security retirement pensions makes a complementary retirement income almost redundant for low and average earners.

- Since existing occupational pension schemes are defined benefits only, the average cost per capita is very high for small schemes. ${ }^{4}$ Therefore, OPSs are almost non-existent among SMEs.

\section{Membership}

Membership of OPSs is determined by a number of employment regulations and court rulings by the Federal Employment Court (Bundesarbeitsgericht) as well as the European Court of Justice. In substance, these regulations restrict German employers from discriminating against single employees or even groups of employees, unless there are factual reasons. However, employers have no obligation to disclose these reasons. Even though, in the case of a tribunal, the burden of proof remains with the employer, employers have 'numerous opportunities' to find such reasons if they have to. Therefore, unlike in the USA, membership of German occupational pension schemes is largely discretionary. ${ }^{5}$ 


\section{Vesting}

The statutory vesting period of German occupational pension schemes is among the longest in the world. Employees aged 35 and older require either:

- ten years of pensionable service; or

- three years of pensionable service, if overall company service is greater than 12 years.

For employees younger than 35 there are no minimum requirements at all. Therefore, the vesting period may be even longer.

\section{Revaluation}

Occupational pensions law requires full revaluation of pensions in payment in line with the consumer price index (CPI). This places an uncertain financial burden on companies in the future and has historically caused them to limit new pension entitlements in the past (see above).

However, the revaluation requirement has been recently amended and any commitment incurred after 1st January, 1999 must be revalued at an annual rate of 1 per cent. Therefore, nothing has changed for commitments incurred prior to that date.

\section{Transfer values}

In Germany, there are neither transfer values for vested benefits nor is there any legal requirement to revalue deferred pensions. Therefore, deferred benefits are constantly reduced in real terms by inflation. Also, the lack of transferability contributes to the fact that the German workforce is less mobile than the workforce of other countries.

As McGill et al. ${ }^{6}$ have shown, without revaluating deferred benefits, the effect of changing employers for a member of a defined benefit scheme can be as much as one-third of the pension. In their example, they are comparing two identical employees of whom the first stays with one employer for the whole of his working life and the other one changes employers once in the middle of his working life.

The latter aspect is especially important since it is widely assumed among economists that the mobility of the workforce between EURO member countries will minimise economic differences, thus effectively replacing the exchange rate mechanism.

\section{Quantitative portfolio restrictions}

Portfolio restrictions vary widely across the four available occupational pension schemes. On the one hand, Pensionskassen and Direktversicherungen are subject to quantitative portfolio restrictions of the Insurance Supervision Law (Versicherungsaufsichtsgesetz, VAG). As a result, portfolios of both consist mainly of fixed-income securities. Holding of equities is restricted to 30 per cent of total assets. However, the actual percentage of equities is even less than that. Pensionskassen, for example, hold only less than 2 per cent equities as a direct investment and, additionally, an estimated 15 per cent in mutual funds (public and special funds). ${ }^{7}$

On the other hand, the asset allocation of support funds is completely unregulated, and investment decisions are made solely by the employer. That is why support funds invest mainly in the sponsoring company. ${ }^{8}$ Also, book reserves, by definition, invest only in assets of the sponsoring company. 


\section{Tax treatment}

At present, Pensionskassen and

Direktversicherungen are taxed using the

T-T-E tax regime (ie, contributions and capital gains are taxed and benefits are tax free). Direktzusagen and

Unterstützungskassen are taxed using the E-E-T tax regime (ie, contributions and capital gains are free of tax, but benefits are taxed).

The different methods can be used because of the concept of 'constructive receipt'. As stated above, beneficiaries of the former do have a legal right to their pension benefits and therefore are liable to income tax, whereas beneficiaries of the latter do not have such a right.

However, employer contributions to Direktzusagen and Unterstützungskassen are taxed differently. Therefore, Germany effectively has three different tax provisions for its four occupational pension scheme types. Furthermore, a number of different income allowances apply to the different types of pension schemes in addition to the general allowances.

\section{Taxation of Direktzusagen}

Direktzusagen incurred after 31st

December, 1986 must be included in the balance sheet as pension liabilities (for commitments incurred before that date, it is optional). ' 'Employer contributions' have the form of new pension liabilities and they are free of tax, if they do not exceed newly accrued benefits for any tax year.

Employee contributions are not allowed, except in the case of deferred contribution arrangements, where deferred income is tax-free for the employee.

For tax purposes, pension benefits of Direktzusagen are treated as income from employment. As such, an initial employee allowance
(Arbeitnehmer-Freibetrag) of $€ 1023$

(DM2,000) may be deduced.

Also, pensioners aged 62 and over may claim a tax allowance of 40 per cent of the benefits received, but no more than $€ 3,068$ (DM6,000) p.a.

(Versorgungs-Freibetrag). No such tax allowance exists for pensioners aged 61 and younger. The excess is known as gross income to which the general income tax allowance still applies (see below).

\section{Taxation of Unterstützungskassen}

Up to a certain limit, employer contributions to Unterstützungskassen are deductible as business expenses. This limit depends on whether the benefits are paid out as a pension or a fixed-term annuity:

- Contributions funding a fixed-term annuity are corporation tax deductible up to 0.2 per cent of payroll annually.

- Contributions to fund a pension are deductible as business expenses, if any of the following conditions apply:

- Contributions to finance pensions in payment (this applies to a PAYG method as well as funding retirement pensions through a lump sum);

- Contributions to fund up to 25 per cent of the expected maximum annual pension; and

- All premiums to a re-insured Unterstützungskasse (Rückgedeckte-Unterstützungskasse). ${ }^{10}$

Employee contributions to Unterstützungskassen are not allowed.

As for Direktzusagen, pension benefits of Unterstützungskassen are categorised as income from employment. Apart from the employee allowance 
(Arbeitnehmer-Freibetrag) of $€ 1,023$

(DM2,000) p.a., pension benefits are taxed at the individual income tax rate of the employee. Again, the general income tax allowance still applies (see below).

\section{Taxation of Pensionskassen and Direktversicherungen}

On the corporate level, employer contributions to Pensionskassen and Direktversicherungen are tax deductible, if one of the following conditions is fulfilled:

- contributions are intended to fund accrued pension liabilities and maintain solvability;

- contributions result from an order of the regulator (BAV); or

- contributions make up for a shortfall between the book value of the assets and the accrued pension liabilities.

On the individual level, because of 'constructive receipt', employee and employer contributions are subject to income tax. However, up to an average of $€ 1,743$ (DM3,408) (maximum $€ 2,147$ (DM 4,200)) p.a. is taxed with a flat rate of 20 per cent (plus a surtax of 2.9 per cent) instead of the individual income tax rate.

For tax purposes, pension benefits are categorised as other income (sonstige Einkünfte) and since contributions have already been taxed, only capital gains (Ertragsanteil) of pension benefits are included in gross taxable income.

\section{General income tax allowances}

In addition to the specific allowances, there are two general income tax allowances in Germany:

- Persons liable to income tax at the age of 64 and older may deduct an age allowance (Altersentlastungsbetrag) of $€ 1,902$ (DM3,720) from their gross income. $^{11}$

- A personal allowance (Grundfreibetrag) of up to $€ 6,902$, (DM13,499) for single/€13,804 (DM26,998) for joint filers is automatically deducted.

Furthermore, the current lack of determination to conduct a pension reform can partly be attributed to the fact that the Supreme Court will publish its ruling shortly. Therefore, all political parties are reluctant to initiate an unpopular pension reform debate only to find out after the ruling that they may have to take it back. Instead, Germany's political parties are perhaps willing to follow the Supreme Court ruling and then have the luxury of blaming that body.

\section{Preliminary conclusion}

The current regulatory environment is very inflexible for both employees and employers and, consequently, it does not promote participation in OPSs. As pointed out above, SMEs hardly offer any occupational pension benefits at all, mainly because it is too expensive.

Larger employers are frequently forced to reduce the benefits provided or even close existing schemes. As a result, each year, fewer employees are provided with pension benefits. This is the main reason why it is widely accepted in Germany that the occupational pension system needs to be reformed.

\section{Occupational pension reform proposals}

\section{Introduction of defined contribution plans}

A crucial step towards improving occupational pension arrangements in Germany would be the introduction of 
defined contribution schemes. Compared to defined benefit schemes, defined contribution schemes have a number of advantages:

- SMEs would be given the opportunity to offer occupational pensions to their staff members

- employer's financial obligations to fund OPSs would be definitively determinable; and

- better transferability would potentially provide better benefits to job changers and therefore would reflect the changed work pattern in the last decades.

In order to take maximum advantage of defined contribution schemes, a variety of different plan types should be introduced:

- money purchase plan;

- a 'stock bonus plan' or an 'employee stock ownership plan (ESOP)'; and

- profit-sharing plan.

The first two, money purchase plan and stock bonus plan/ESOP, should be used as the base plan where the employee, and possibly also the employer, makes contributions on a regular basis, ideally monthly. This base plan could be complemented by a profit-sharing plan.

With such a design, it is likely that the capital inflow would be sufficient to build up a substantial fund for retirement. Also, since the top-up plan is a profit-sharing arrangement, it is especially suitable for smaller employers. Profit-sharing plans do not require a long-term financial commitment and they are relatively easy to administer, which makes them significantly cheaper than other types.

Given that there is sufficient choice, employers could choose a plan that is tailored to their business objectives and likely to reflect the needs of their employees.

\section{Funding}

Currently, only Pensionskassen and Direktversicherungen must be fully funded. Direktzusagen build up pension assets on the balance sheet of the sponsoring company. The funding level of Unterstïtzungskassen depends on the benefit provided and whether the scheme is re-insured (see above). Only re-insured Unterstützungskassen may be fully funded for tax reasons; any other arrangements are usually underfunded.

In order to reduce the bankruptcy risk of the sponsoring company ${ }^{12}$ and to improve the allocation efficiency of pension assets, the following changes should be considered:

- outsourcing pension assets of Direktzusagen from the company's balance sheets to separate funds; and

- fully funding Unterstützungskassen regardless of the funding structure used and benefits provided.

For the former suggestion, there is currently no viable solution in German company and tax laws. ${ }^{13}$ This issue must be addressed publicly in order to find a reasonable solution.

\section{Portfolio regulations}

Asset allocation of the four German occupational pension vehicles should be brought in line with the long-term investment goal of retirement savings. Ideally, as the investor is still young, most or all of the assets should be invested in equities. The exact distribution between equities and other less volatile assets depends solely on the individual investor's tolerance of risk. As the investor approaches retirement, 
equities should be exchanged for fixed-income securities to reduce the risk of short-term volatility of equity prices. This method is known as age-phasing and was first described by Samuelson. ${ }^{14}$

As pointed out above, Pensionskassen and Direktversicherungen are legally categorised as insurance companies and therefore are regulated by the insurance supervision law (VAG). According to the VAG, insurance companies are subject to a minimum return of investment of 3.25 per cent p.a. (the rate was reduced from 4 per cent in 1999). Hence, the higher volatility of equity prices compared to fixed-income securities affects both vehicles in a way that they need to invest the majority of assets in fixed-income securities in order to fulfil the statutory return-of-investment goal.

Clearly, the short termism of the German VAG is counterproductive, since it prevents insurance companies from maximising their long-term investment return. There are two possible solutions to this problem: either drop the short-term investment return goal of the VAG for Pensionskassen and Direktversicherungen, or set up new instruments with longer-term investment return goals. Both options are viable solutions and a decision for either of them needs to be discussed in more detail. However, given the strong (short-term) risk adversity of German investors, higher equity investment for existing life insurance contracts must be considered very carefully.

Nevertheless, the current regulatory environment of quantitative portfolio restrictions should be brought in line with maximising long-term returns. Therefore, independent asset managers should be given the responsibility to manage the assets of outsourced Direktzusagen and fully funded support funds.

\section{Consistency in terms of taxation}

Consistent tax treatment of retirement arrangements is vital for an efficient retirement system. As pointed out above, there is no consistent tax treatment of retirement provisions whatsoever. This causes a significant loss in allocation efficiency in the economy as a whole.

Both tax regimes currently used have certain advantages and disadvantages. For the T-T-E tax regime, the most difficult problem is the distinction between capital repayments and capital gains, even though it is straightforward for fixed-term annuities. The calculation of the capital gains for a purchase life annuity can be achieved only by using actuarial assumptions. Therefore, this tax regime involves unequal tax treatment because of the redistribution of tax liabilities from pensioners who die early to those who exceed average life expectancy.

The E-E-T tax regime involves the problem of differentiating between vehicles designated for retirement saving and other savings vehicles. However, this problem can be solved simply by definition: certain instruments will qualify as retirement arrangements, whereas others will not. Therefore, contributions to the former will be exempt from income tax and contributions to the latter will have to be made after tax. Furthermore, abuse of the preferential tax treatment of retirement saving must be avoided. Therefore, it is necessary to:

- tie the withdrawal of funds to a minimum age (eg, 60);

- apply a penalty tax to funds that are withdrawn before reaching the minimum age (the tax rate should be equal to the personal income tax rate of the investor); and

— disallow using retirement assets as collateral for a loan. 
Also, the E-E-T tax regime is likely to result in lower lifetime tax liability as the T-T-E tax regime, because of a deferral of tax liability and a lower marginal income tax rate that usually applies simply because the overall income of the investor is lower.

As a result, from an employee perspective, the E-E-T regime is on balance likely to be superior to the T-T-E regime and should be used consistently for all types of occupational pension schemes. That way, individuals who have paid contributions for all of their working life and die on the very first day of retirement would, at least, not have paid any income tax.

\section{Membership}

Instead of effectively allowing employers to make discretionary decisions upon OPS membership on an almost individual basis, employers should have the statutory duty to apply and communicate objective membership conditions. With such a solution, compliance with non-discrimination requirements could be improved significantly and the number of industrial tribunals related to pension issues could ultimately be reduced.

\section{Vesting}

The current statutory vesting requirements of German OPSs are far too extensive. The vesting periods of ten years or three years with a 12 -year service requirement for employees aged 35 and over do not reflect the changed work environment nowadays. The same is true for employees aged 34 and under, who do not have a minimum vesting period at all.

Instead, if the statutory vesting period was reduced to a maximum of two years, as in the UK, the following benefits would probably be available:

- increase in labour mobility, because employees do not get locked into organisations until their benefits become vested, especially in the absence of transfers; and

- a potential conflict with the introduction of defined contribution plans could be avoided.

\section{Revaluation}

The current obligation of employers to revalue pensions in payment in line with the CPI places an indefinite financial burden on employers and is perhaps the greatest reason for the decreasing participation in German OPSs.

Therefore, following the example of the UK, pensions in payment should be revalued by a limited price inflation of 3 or even 4 per cent compound. That way, the overall financial burden for employers would be capped and, at the same time, pensions in payment would provide a sufficient protection against inflation for employees.

Furthermore, there are currently some OPSs where membership is compulsory and, in the event of leaving the company, vested benefits are neither transferable nor will they be revalued. As a result, the purchasing power of deferred pensions is likely to be eroded by inflation. In order to prevent this from happening, deferred pensions should be revalued in the same way as pensions in payment.

\section{Preliminary conclusion}

Among the reform issues discussed above, the introduction of defined contribution schemes and membership have little or no financial consequence for the parties involved. Therefore, both measures could be introduced right away. 
The other issues - funding, portfolio regulations, vesting and revaluation may likely have financial implications, mainly for employers. Therefore, those must be considered more carefully. Nevertheless, every single measure is important and only by introducing most or all of them, it may be assumed that an increasing number of employers, regardless of their size, will grant (new) pension benefits.

\section{Alternative solutions for providing adequate pension benefits}

\section{Volkswagen model}

In cooperation with the HypoVereinsbank, Germany's second-largest commercial bank, and with the consent of local tax authorities, Volkswagen used the Flexible Work Time Act of 1998 (Gesetz zur sozialrechtlichen Absicherung flexibler Arbeitszeiten) to set up a deferred compensation plan. Under this arrangement, employees may convert their overtime payments into deferred contributions to a pension plan, which are being paid into the plan by the employer net of income tax.

An investment committee, consisting of an employee representative, the personnel director of Volkswagen and a representative of HypoVereinsbank, sets out the investment principles of the plan. These principles function as guidelines for the currently five professional asset managers. At the moment, a maximum of 30 per cent is invested in equities, in order to establish trust with German investors. In the long run, equity holdings are expected to increase to 70 per cent, in line with British and American pension funds. Additionally, the plan must not invest in South American and Asian securities as well as securities issued by Volkswagen. ${ }^{15}$
The Volkswagen model is an innovative example of how to achieve a favourable tax treatment (E-E-T tax regime) with the consent of the local tax authorities. Even though the collective bargaining parties have just recently agreed to promote the Volkswagen model, ${ }^{16}$ it remains to be seen whether the tax authorities give their consent. But, instead of introducing the E-E-T tax regime through the back door, it would be more efficient to do it openly for all OPSs.

\section{Employer-provided mutual funds}

An increasing number of German multinationals are using mutual funds to provide retirement income for participating employees. These funds are set up either as special or public funds. Employer-provided mutual funds have a number of advantages compared to traditional OPSs, from both an employer's and employee's perspective.

Employees benefit from:

- potentially higher long-term investment returns through a greater investment in equities compared to the current bias towards fixed-income securities of the average German investor;

- low costs in comparison to individual mutual funds and OPSs;

- easy access, since administration is handled directly by the personnel department of the employer in co-operation with the investment company; and

- superior communication, because of extensive reporting and disclosure requirements of funds and daily price publication.

Employers prefer these arrangements to proper OPSs for the following reasons: 
Table 2: Employer-provided mutual funds offered to German employees

\begin{tabular}{|c|c|c|c|c|}
\hline Sponsor & Name of plan & $\begin{array}{l}\text { Total } \\
\text { employees }\end{array}$ & $\begin{array}{l}\text { Plan } \\
\text { members }\end{array}$ & Main asset type \\
\hline Daimler-Chrysler & $\begin{array}{l}\text { GD Aktienfonds DWS } \\
\text { KB Vorsorgeplan dbi }\end{array}$ & 230,000 & $\begin{array}{l}10,000 \\
\text { N/A }\end{array}$ & $\begin{array}{l}\text { Intl. equities } \\
\text { AS-Fonds }\end{array}$ \\
\hline Deutsche Lufthansa & $\begin{array}{l}\text { Albatros Fonds } \\
\text { Albatros Aktien Euro }\end{array}$ & 55,000 & $\begin{array}{l}\text { N/A } \\
\text { N/A }\end{array}$ & $\begin{array}{l}\text { Intl. equities and bonds } \\
\text { European equities }\end{array}$ \\
\hline ESSO & dbi-ESSO-Fonds & 1,400 & $\mathrm{~N} / \mathrm{A}$ & Bonds \\
\hline Ford & $\begin{array}{l}\text { FW Select I OP } \\
\text { FW Select II OP }\end{array}$ & 44,000 & $\begin{array}{l}\mathrm{N} / \mathrm{A} \\
\mathrm{N} / \mathrm{A}\end{array}$ & $\begin{array}{l}\text { Intl. bonds } \\
\text { Intl. equities }\end{array}$ \\
\hline Henkel & $\begin{array}{l}\text { Löwen-Aktienfonds } \\
\text { Leo-Fonds }\end{array}$ & 9,600 & $\begin{array}{l}2,200 \\
\text { N/A }\end{array}$ & $\begin{array}{l}\text { Intl. equities } \\
\text { Intl. bonds }\end{array}$ \\
\hline Schering & Lea-Fonds DWS & 10,000 & 1,400 & European equities \\
\hline
\end{tabular}

Source: Handelsblatt.

- the financial obligation is definitively determinable;

- mutual funds are significantly cheaper than traditional defined benefit plans, especially for SME; and

- providing these benefits increases the bond between participating employees and the employer and may even give the employer a competitive advantage over competitors that do not provide these or similar benefits.

Among the multinationals offering at least one employer-provided mutual fund to their German employees are Daimler-Chrysler, Deutsche Lufthansa, ESSO, Ford, Henkel and Schering (see Table 2). ${ }^{17}$

Except for the case of ESSO, participating employees in all other companies are able to invest their assets in equities. Together with $85 \mathrm{~m}$ life insurance contracts (ie, on average one per citizen), which invest mainly in fixed-income security, these equity funds may balance the retirement portfolios of German investors. Additionally, Daimler-Chrysler is the first company to offer their employees a recently introduced pension investment fund (see below).

Given the absence of both defined contribution schemes and transfer values for defined benefit schemes, employer-provided mutual funds are possibly the next-best solution for providing employee savings/retirement schemes. Therefore, company-provided mutual funds are a viable solution.

\section{Pension investment funds}

Some of the employer-provided mutual funds are the so-called 'AS-Fonds' (Altersvorsorge-Sondervermögen; pension investment funds). AS-Fonds were introduced to the investment company law (Gesete über Kapital-anlagegesellschaften) in April 1998. The strategic objective of these funds is to provide retirement benefits for employees and private investors using the existing structure of open-end investment funds. The basic characteristics of $A S$-Fonds are as follows:

- high flexibility

- high security through use of existing regulatory environment of the German investment fund industry

- efficient investment strategy that is very similar to British and American pension funds (even though quantitative portfolio restrictions are being used instead of the 'prudent man rule'); and

- no preferential tax treatment.

Although the basic features of pension investment funds have been discussed by Laux, ${ }^{18}$ two important issues have not 
been covered, namely the first figures for investment returns and the cost issue. Therefore, this paper will focus on them.

\section{Investment returns}

Obviously, one year is not long enough to judge investment returns of a retirement vehicle, but as of 31st May, 2000, AS-Fonds have achieved an average investment return of 37 per cent. This is well above the 21.9 per cent investment return of the most commonly used benchmark for mixed funds, ie, this benchmark consists of 50 per cent international equities (MSCI world) and 50 per cent international fixed-income securities (Salomon-Brothers-Index). ${ }^{19}$

The best-performing fund managed a remarkable 118.4 per cent. Similar to the other four top-performing pension investment funds, equity investment was close to its maximum of 75 per cent of fund assets (see Table 3). Therefore, the top-performing funds benefited largely from the high equity returns in the fourth quarter 1999 and the first quarter 2000.

On the contrary, the worst-performing fund managed an investment return of only 11.3 per cent. Similarly, the other four funds on that end of the ranking, this fund invested heavily in fixed-income securities and real estate (see Table 3).

This is certainly not enough evidence for higher investment returns of equities over fixed-income securities in the long run. But it points in the right direction.

\section{Cost}

Despite the widespread overperformance in the first year of existence, pension investment funds are generally not very cost efficient. Especially in the long run, investment returns and capital gains are partially offset through a high fee structure.

Analysing the cost structure, there are typically four different fees charged to pension investment funds:

— bid-offer spread;

- management fee (Mgmt fee);

— custodian fee; and

- annual account fee (A/C fee).

Table 4 shows these different charges that apply for each 'AS-Fonds' as well as the average charges for all funds. Also, the total $\operatorname{costs}^{20}$ are calculated which are DM3,101.20 for the cheapest fund and DM8,422.96 for the most expensive fund. These amounts equal 9.8 per cent of total contributions for the former and 26.7 per cent for the latter.

The following points should be noted:

- the bid-offer spread is charged on contributions to the fund. It is usually argued that it is charged to cover the marketing and administrative costs of investment companies. However, there are currently two no-load funds offered by direct brokers and the average bid-offer spread of pension investment funds is 3.45 per cent.

- The management fee is charged in regular intervals (either quarterly or annually) on the assets of the fund. It compensates the investment company for active fund management. The management fee varies between 0.5 per cent for the cheapest funds to 1.5 per cent for the most expensive fund. In the long run, the management fee has the most significant impact on the overall cost of a fund, because of its recurring nature. The average management fee of pension investment funds is 0.86 per cent per annum.

- All assets must be held by a custodian (usually a bank) that is a separate legal entity from the investment company. This custodian may charge a regular fee (mainly on an annual basis) for its services. The fee is expressed as a 
Table 3: Asset allocation and one-year investment returns of pension investment funds as of 31st May, 2000

\begin{tabular}{|c|c|c|c|c|c|c|}
\hline Rank & Name of fund & Equities & $\begin{array}{c}\text { Asse } \\
\text { Bonds }\end{array}$ & $\begin{array}{l}\text { allocation } \\
\text { Real estate }\end{array}$ & Cash & One-year return \\
\hline 1 & ADIG AS-Aktiv Dynamik & $71.9 \%$ & $18.0 \%$ & $0.0 \%$ & $9.7 \%$ & $118.4 \%$ \\
\hline 2 & DWS Vorsorge AS (Dynamik) & $66.0 \%$ & $27.0 \%$ & $0.0 \%$ & $7.0 \%$ & $74.9 \%$ \\
\hline 3 & Deka-PrivatVorsorge AS & $67.0 \%$ & $15.7 \%$ & $10.3 \%$ & $7.0 \%$ & $77.6 \%$ \\
\hline 4 & Gerling AS & $72.2 \%$ & $19.8 \%$ & $0.0 \%$ & $8.0 \%$ & $72.1 \%$ \\
\hline \multirow[t]{2}{*}{5} & HansaAS & $59.2 \%$ & $0.0 \%$ & $27.2 \%$ & $13.6 \%$ & $66.2 \%$ \\
\hline & Arithmetic mean & & & & & $37.0 \%$ \\
\hline 32 & ADIG-Zukunft 3 AS & $54.6 \%$ & $34.9 \%$ & $0.0 \%$ & $10.5 \%$ & $18.8 \%$ \\
\hline 33 & BWK-Kontinuität & $39.4 \%$ & $36.0 \%$ & $21.3 \%$ & $3.2 \%$ & $18.3 \%$ \\
\hline 34 & DIT Altersvorsorge AS 55plus & $40.0 \%$ & $45.0 \%$ & $15.0 \%$ & $0.0 \%$ & $15.7 \%$ \\
\hline 35 & DIT Altersvorsorge AS 55 & $50.0 \%$ & $35.0 \%$ & $15.0 \%$ & $0.0 \%$ & $15.3 \%$ \\
\hline 36 & FT Life-Invest Classic & $39.6 \%$ & $41.3 \%$ & $15.2 \%$ & $3.9 \%$ & $11.3 \%$ \\
\hline
\end{tabular}

Source: Handelsblatt; BVI; Kapitalanlagegesellschaften.

percentage on the assets of the fund. Some custodians do not charge a fee, mainly because the investment company is a subsidiary. Others charge as much as 0.50 per cent per annum with an average of 0.11 per cent.

- An investor also has to set up an account with the custodian, which may involve additional charges. Some custodians charge an annual account fee of as much as DM41.76 per annum (inclusive of VAT). However, the average annual account fee is DM13.38.

There are possibly two reasons why $A S$-Fonds are relatively expensive. First, since this is a relatively new instrument, the size of funds is still relatively small and therefore there are only minor economies of scale. Currently, 44 $A S$-Fonds have been set up with total assets of DM4.36bn as of 31st May, 2000. This equals an average fund size of DM99.09m. Evidently, so far, the size of the fund seems not to have had a significant impact on the cost structure, because three of the largest funds, the DIT-Altersvorsorge 35, 55 and 55plus, are also among the most expensive.

Secondly, traditionally the investment sector in Germany is dominated by only four investment companies: Union
Investment (a joint subsidiary of Commerzbank and HypoVereinsbank), DeKa (a subsidiary of the German savings and loan institutions), Dresdner Bank Investment Group and Deutsche Bank Investment Group. These four groups have a combined market share of 71.3 per cent with respect to total assets of pension investment funds (and a similar market share overall). Thus, there is hardly any competitive pressure to reduce margins.

Furthermore, the behaviour of German investors further contributes to the de facto oligopoly in the investment market. Consumers tend to bank with the branch that is most convenient to them instead of shopping around for the best rates. Since German banks typically offer only funds of their own investment subsidiary, investors tend to make their investment decisions only on a limited number of funds, which are not necessarily the cheapest ones, given that the above-mentioned groups have the most branches.

However, AS-Fonds are a valuable addition to the German retirement market, even without any tax concessions. This is already reflected in very promising investment returns. Given the experience in the UK and the USA, it is anticipated that, in the long run, 
Table 4: Expenses of pension investment funds as of 31st May, 2000

\begin{tabular}{lllllrl}
\hline \multirow{2}{*}{ Rank } & Name of fund & $\begin{array}{l}\text { Bid-offer } \\
\text { spread }\end{array}$ & $\begin{array}{l}\text { Mgmt } \\
\text { fee }\end{array}$ & $\begin{array}{l}\text { Custodian } \\
\text { fee }\end{array}$ & A/C fee & $\begin{array}{l}\text { Total } \\
\text { costs }\end{array}$ \\
\hline \multirow{2}{*}{1} & Degussa Bank Universal & $2.50 \%$ & $0.50 \%$ & $0.10 \%$ & 0.00 & $3,101.20$ \\
2 & ADIG AS-Aktiv Plus & $3.00 \%$ & $0.50 \%$ & $0.06 \%$ & 17.40 & $3,418.32$ \\
3 & ADIG AS-Aktiv Dynamik & $3.00 \%$ & $0.50 \%$ & $0.06 \%$ & 17.40 & $3,418.32$ \\
4 & BfG Invest Generation plus & $3.00 \%$ & $0.50 \%$ & $0.15 \%$ & 0.00 & $3,451.80$ \\
5 & BWK Konzept Zukunft AS & $2.00 \%$ & $0.70 \%$ & $0.05 \%$ & 13.00 & $3,755.00$ \\
& Arithmetic mean & $3.45 \%$ & $0.86 \%$ & $0.11 \%$ & 13.38 & $5,163.74$ \\
34 & BWK-Kontinuität-AS & $2.50 \%$ & $0.80 \%$ & $0.05 \%$ & 13.00 & $6,994.60$ \\
35 & BWK-Dynamik-AS & $2.50 \%$ & $0.80 \%$ & $0.05 \%$ & 13.00 & $6,994.60$ \\
36 & FT Life-Invest Classic & $5.00 \%$ & $1.25 \%$ & $0.10 \%$ & 17.40 & $7,093.40$ \\
37 & GAMAX AS Classic Zürich Invest & $5.25 \%$ & $1.50 \%$ & $0.04 \%$ & 41.76 & $8,342.76$ \\
38 & MK Viva & $5.26 \%$ & $1.44 \%$ & $0.12 \%$ & 41.76 & $8,422.96$ \\
\hline
\end{tabular}

$A S-F o n d s$ will significantly outperform any other existing retirement vehicle, especially OPS and life insurance contracts, and therefore justify their existence. And through the increasing number of online banks and online brokers in Germany the competitive pressure has already started to grow, which will eventually force investment companies to reduce their fees.

\section{Conclusion}

Declining participation in occupational pension schemes and innovative alternative solutions by German companies to provide employee benefits clearly show that there is a need for reform. At the moment, legislators seem reluctant to make any decision in this regard, because of the expected ruling of the German Supreme Court. Depending largely on the budgetary restraints at the time of this ruling, legislators may include the second tier in that pension reform (ideally all three tiers will be included), thus, hopefully, at least creating a taxation level playing-field. This would, at least, give employers the freedom of choice between existing types rather than making that choice mainly for tax reasons, which seems to be common practice at the moment.

The introduction of defined contribution schemes (including pension investment funds) and changing membership provision per se do have little financial implication for current providers of OPS. Therefore, there is hardly any excuse for not including defined contribution schemes in the occupational pensions law.

The other reform issues mentioned in this paper - funding, portfolio regulations, vesting and revaluation have more or less significant financial implications for employers, even though legislators are responsible for the design of the pension reform. Support of the German Employers Association (Arbeitgeberverband) would be desirable in order to maximise the take-up rate and, thus, achieve widespread participation. It is essential that German employers understand the importance of a competitive occupational pension system in order to attract and retain talent on the world labour market. As a result, all parties of interest should finally start working together and do what has been long overdue: design a consistent, farreaching, long-term occupational pension reform.

\section{References}

1 Davis, E. Philip (1995) 'Pension Funds, Retirement Income Security and Capital Markets - An International Perspective', Oxford, p. 66. 
2 'Pensionskassen' under supervision of the Federal regulator only.

3 Ruppert, Wolfgang (2000) Betriebliche Altersversorgung: Heue ifo Erhebung zeigt Stabilisierungstendenzen; in: ifo Schnelldienst 21/2000, 53. Jahrgang, 25. Juli, pp. 24-32.

4 According to Mitchell, Olivia S. (1996) 'Administrative Costs in Public and Private Retirement Systems'; in: 'Pensions Research Council' (Eds): Working Paper Series, No. 96-4, Philadelphia, pp. 17 and 25, the design of defined contribution schemes tends to be more standardised (eg, through the use of mutual funds) and it is therefore less expensive than defined benefit schemes. Also, the regulatory environment requires defined benefit schemes to incur certain costs that are non-existent for defined contribution schemes (eg, actuarial valuations and premiums to the PSVaG).

5 Doetsch, Peter A. (1997) 'Die Möglichkeiten der Differenzierung in der betrieblichen Altersversorgung'; in: 'Betriebliche Altersversorgung' 1/97, 7th February, p. 25

6 McGill, Dan M., Brown, Kyle N., Haley, John, J. and Schieber, Sylvester J. (year) 'Fundamentals of Private Pensions', 7th edition, p. 486.

7 Schwind, Joachim (1998) 'Bericht der Leitung der Fachvereinigung Pensionskasse' in 'Betriebliche Altersversorgung', 5/98, 31st July, p. 182.

8 Röseler, Raimund (1998) 'Betriebliche Altersversorgung'; in 'Deutscher Sparkassen- und Giroverband e.V.' (Eds): Sparkassenheft 165, Stuttgart, p. 32

9 However, there are few legal conditions, before a 'Direktzusagen' may be incurred: (1) members must be given a legal right to their benefits; (2) the pension commitment must not be cancellable arbitrarily; (3) it must be given in writing; and (4) only members, who have reached age 30 in the middle of the plan year may be included ( $\$$ 6a EStG).

$10 \$ 4$ d Abs. 1 EStG.

$11 \llbracket 24$ a Satz 1 EStG.

12 The bankruptcy risk concerns the PSVaG and active employees, but to a much lesser extent pensioners, since their full benefits are guaranteed.

13 Merz, Friedrich (2000) 'Die Zukunft der betrieblichen Altersversorgung'; in 'Hoppenrath', Martin/Wohlleben, Hermann Peter (Eds): Positionen - 25 Jahre Pensions-Sicherungs-Verein, Köln, p. 74.

14 Samuelson, Paul (1989) 'A case at least for age-phased reduction in equity'; in 'Proceedings of the National Academy of Science', Washington.

15 Pauly, Christoph (1999) 'Das VW-Modell'; in Der Spiegel No. 51/20th December, pp. 82-84.

16 Handelsblatt, 12th July, 2000/No. 132, p. 2.

17 Narat, Ingo (1999) 'Experten erwarten Boom bei Firmenfonds', in Handelsblatt, 10-11th December, No. 240, p. 45.

18 Laux, Manfred (1999) 'Germany: The personal pension funds for the second and third pillar', Journal of Pensions Management, Volume 4, Number 4, July, pp. 339-356.

19 Handelsblatt, 14th June, 2000, No. 113, p. 47.

20 The total costs have been calculated on the assumptions that an investor puts a lump sum of DM10,000 in the account and makes monthly contributions of DM100 for a period of 18 years (statutory minimum). To keep calculations simple, it is further assumed that the inflation rate is zero and there are no investment returns. Therefore, total

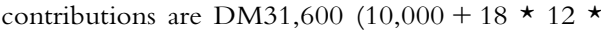
100). 